\title{
Improvement of Small Board Listed Company's Internal Accounting Controls
}

\author{
Dan Wang*, Fengxia Zhou \\ Beijing Wuzi University, Beijing, China \\ Email: wangdan9080@sohu.com,948148335@qq.com
}

Received 31 May 2016; accepted 18 July 2016; published 21 July 2016

Copyright (C) 2016 by authors and Scientific Research Publishing Inc.

This work is licensed under the Creative Commons Attribution International License (CC BY). http://creativecommons.org/licenses/by/4.0/

\section{Abstract}

In the increasingly competitive market of today's society, to survive has been inseparable from the development of internal accounting controls for enterprises. Practice has proved that the internal accounting control system is an important component of modern enterprise management, is to ensure sustained and healthy development of enterprises and is an essential element of business success. Since the small and medium-sized board listed company went public in 2004, the relevant departments of China continue to raise its operating characteristics, revise and supplement the relevant accounting regulations. However, the internal control of the enterprise remains a problem, therefore, to strengthen internal accounting control construction can be said to have emerged. Small plates listed family companies control more serious, the chairman has the absolute controlling stake in that company's separation of ownership and management is very low. Based on these problems, in combination with the actual situation of small and medium-sized boards of listed companies, we can learn more mature theory of internal accounting control, analyze deeply and research the problems of internal accounting control, and put forward the countermeasure and the suggestion. Its purpose is to help rationalize business activities, legalization, in order to improve economic efficiency of enterprises. Sound and effective internal accounting controls can help identify the small board listed company's internal accounting control deficiencies, and the analysis of practical problems will promote a more efficient and healthier development for the small plate of listed companies. To combine the actual situation and the theoretical basis of the small and medium-sized boards of listed companies, it can provide better suggestions and comments for the internal control system, so that through a more scientific analysis of the internal accounting control of small and medium-sized boards of listed companies, to identify existing problems, we can put forward a reasonable approach.

\section{Keywords}

Small Plates, Internal Accounting Controls, Improvement

\footnotetext{
"The first author.
} 


\section{The Background of the Study}

With the rapid development of China's socialist market economy and the deepening of the market economy, the development of production technology has greatly improved the social productive forces and gives the unlimited development opportunities to the enterprise, so that the enterprise needs to constantly improve their own management level and ability to resist risks [1]. Modern enterprises need to specially improve the enterprise's internal accounting control, because internal accounting controls play an important role in business management, which is an important means to effectively strengthen the financial management, and will help improve the company's core competitiveness and market competition force. China has promulgated a series of internal control standards, for example: in June 2008, five ministries jointly issued the "basic norms of internal control”, and in July 2009 implemented within the scope of the listed companies. Because of its size and structural characteristics of small plates listed companies, its internal control is not very mature, and there is still the root of all kinds of enterprises in the internal control problems. Sound and effective internal accounting control system that can help small plates listed companies to find defects and deficiencies of internal accounting controls exists in this study to identify problems. Therefore, the small and medium-sized boards of listed companies can reach to a long-term health development.

\section{The Present Situation of the Domestic and Foreign Research}

\subsection{Foreign Research Status}

In 2001, Enron shocked the world, after the outbreak of a series of scandals exposed the well-known US companies, and systems of internal extreme irrationality, in order to save the public's trust, the US Congress introduced a well-known Sarbanes-Oxley Act “the bill 404 provision requires the company's management on the effectiveness of internal control disclosure.

Cooke [2] developed a sample of 48 Japanese companies, he believes that the internal control information disclosure of listed companies are affected by the level of position, industry type and other factors. The results show that the size of the company and the internal control information disclosure positive correlation.

Simmon (1999) believed that with the separation of ownership and management of enterprises, more and more responsibility and corporate managers have to face greater foreign competition, which allows enterprises to realize an effective improve the core competitiveness of enterprises will be a key factor It is to strengthen the internal control of enterprises.

In 2002, the internal control information of the American professor William in 1990 to the beginning of the century was researched, the paper summarizes the problems that affect the company's internal control management. On this basis, analyzes the impact of the company's internal control management, good internal controls enables the company's management more effective. Through effective internal controls, company executives can make the right and get the various sectors more effective supervision and mutual restraint. Reduce the level of abuse of rights of the company.

Bupa (2004) considered in accordance with the mandatory "Sarbanes-Oxley Act", the disclosure of internal control information to the enterprise brings greater cost. Maria, Subramanyam and Raghunadan [3] researched the company's information disclosure, and they found that compared with no defects, the enterprise needed more cost to disclose internal control defects.

Hammersly, Myers and Catherine [4] used empirical methods to verify the auditor's audit capacity, disclosure of ambiguity, management's seriousness and manager of internal control evaluation of the results of the implementation of internal control to substantive control deficiencies correlation.

\subsection{Domestic Research Status}

Chen Lijun [5] discussed the existing problems, how to improve the accounting internal control Chinese enterprises, enterprise urgent questions and issues raised for the relevant countermeasures.

Liu Ning [6] discussed the Chinese internal accounting controls has formed a reasonable and effective system, especially the "Accounting Law" and "Internal Accounting Control Standards” promulgated since, a strong impetus to the Internal Accounting Control development, deepening reform of enterprises to promote the modern enterprise system has played a good role.

Zhou Xiuhua [7] showed that SME managers should be deep into every corner of the enterprise, to understand the 
actual situation of enterprises, according to local conditions to develop internal accounting control system of the unit.

Feng Sixian developed 201 A-share listed companies in the sample, he thinks the level of internal control information disclosure by Profitability (ROE) influence, the results show that earnings performance was significantly positively correlated with the level of disclosure.

Cai Jeep developed the A-share listed companies in the sample, the factors affecting the depth of internal control information disclosure of listed companies in China horizontal wells. He believes that the company's profitability, financial condition and quality of financial reporting anomalies affecting internal control information disclosure of listed companies in China level. Study results show that high quality and good performance of corporate annual reports tend to disclose more information on internal control, signaling theory is more, the company disclosed more internal control information, the more it can reflect the company's good management, thereby financing investment company has a positive impact. In contrast, the poor quality of financial reporting and poor performance of the company do not want to disclose more information about internal controls.

By analyzing the internal history of domestic and foreign control theory, it can be seen that internal control is the most important part of the internal accounting control, it has not changed.

As can be seen from the historical research of foreign scholars, foreign internal control system is mainly defined by the practitioners to empirical analysis method, and more from the audit and oversight stance evaluation and understanding. China internal control theory is compared to western countries started late, at present China's internal accounting control system in developed countries, there are still some gaps. The entire theoretical studies as well as the lack of lack of internal controls led to Chinese companies a lot of problems, and not an effective solution. For Chinese internal control deficiencies at present, relevant Chinese researchers in China to improve the efficiency of internal control purposes has been well studied.

\section{The Control's Forms and Problems of Small Board Listed Company's Internal Accounting Control}

\subsection{The Control's Forms of Small Plates}

According to the nature of corporate, the control's form of small plates is divided into the following forms. Figure 1 shows the typical control diagram form of the central enterprises, from Figure 1, we know the relationship between small and medium-sized plate company and other companies; Figure 2 shows the another form of control of the holding private enterprises, from Figure 2, we know the location of the small and medium-sized plate company basing on the perspective of the holding private enterprises; Figure 3 shows the typical control forms of the family business, from Figure 3, we know the possible links among members of the family of the small and medium-sized enterprises.

\subsection{The Control's Problems}

\subsubsection{The Weak Consciousness of Internal Accounting Control}

For a long time, due to the impact of the planned economy and traditional management ideas and methods, the

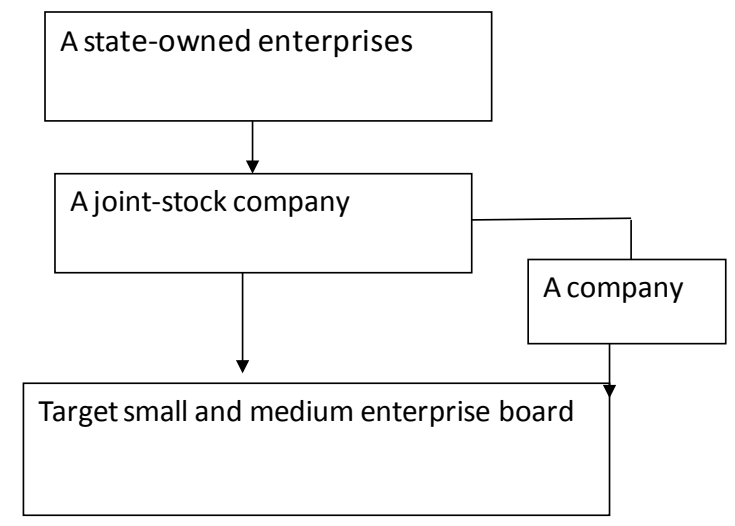

Figure 1. Central enterprises typical control diagram form. 


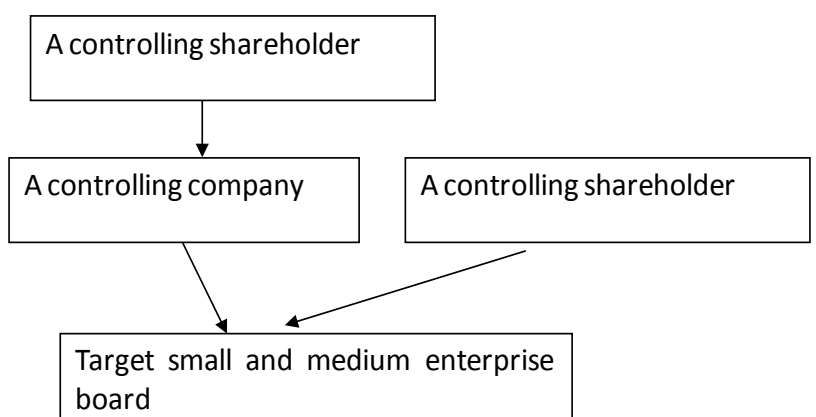

Figure 2. Private enterprises holding another form of control.

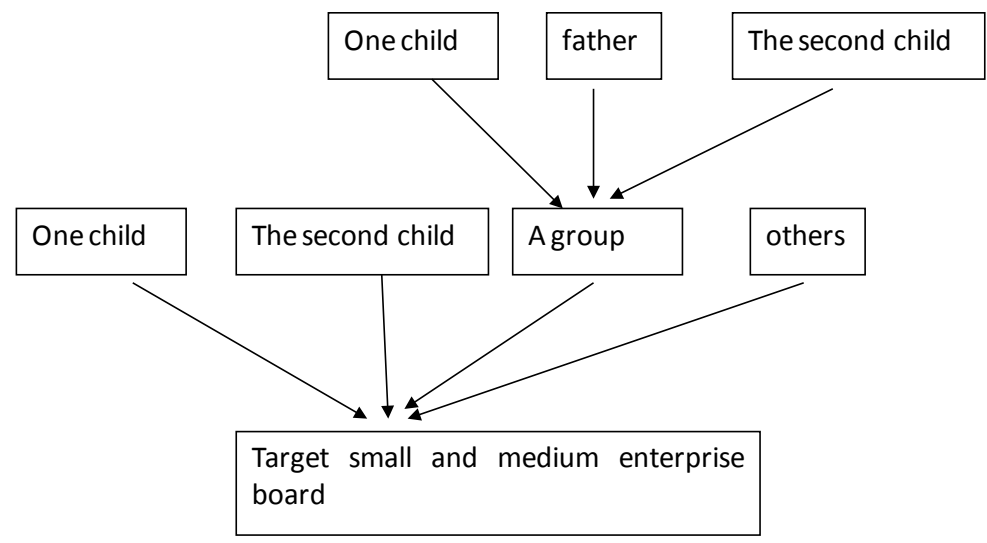

Figure 3. Typical forms of control of the family business.

company emphasis on internal accounting control is not enough, in violation of the established rules and regulations of the phenomenon everywhere. The person in charge of accounting work on administrative intervention, resulting in internal accounting oversight formality, distortion of accounting information, accounting disorder, accounting functions have not been fully effective play. Due to the small board listed companies is more concentrated, more connected shareholders than the motherboard market more prone to the controlling shareholders funds or provide funding for related party companies. The main cause of this situation is that most small board listed company executives to inadequate internal accounting control theory and master less knowledge, reach the understanding and development of the internal control system synchronization requirements. In addition, many small plates listed companies have a strong sense of centralization, there is no realization of the right balance between departments, as multiple roles, not really lead to the implementation of internal accounting controls, or even deformed. Because leadership inadequate attention, resulting in corporate accounting and other personnel disregard internal accounting control system, intentionally or unintentionally weaken the internal accounting control system.

\subsubsection{Internal Audit Did Not Play Its Due Role}

Internal audit is an important measure to improve the internal self-monitoring mechanism for restraint to protect the interests of the owners, but also to ensure that accounting information is true and complete an important tool. China's small and medium enterprise board of the internal audit department better, but there are still a few companies that have yet to establish an independent internal audit organization or the full-time staff is not configured. Since the internal auditor must be responsible for the top leaders of the enterprise, and its staffing, career development, working conditions and other leaders decided by the company, resulting in the internal audit is not independent in the work, organization and economy, dependent on business leaders. The formation of internal audit report, internal audit decisions, and the use of all the other units still depend on the consciousness and behavior of the leadership. From the operational and supervisory cooperation process perspective, the right to supervise the powerless who most effective, superior authority subordinate the most significant effect, monitoring between peers, because the power is equal, compete with each other constraints, the effect is greatly re- 
duced, and supervise subordinates superiors, not only can not have a direct impact, and will have a negative effect, they tend to bring superior to subordinate repression revenge.

\subsubsection{Low Quality of Enterprise Managers}

Most of the qualities of personnel small plates listed companies were lower, because of size limitations, most companies follow the governance structure and staff positions pre-IPO allocation. Its management of cultural literacy and professional staff underlying level are relatively low. Due to differences in professional quality and operational ability of managers on the result there are still many problems in internal management and internal accounting control. Specific performance in several ways: internal management system slack internal accounting control structure system is not perfect, the department is unclear; internal audit control incomplete, leading to confusion accounts; incompatible violate the principle of separation of duties, the post office is unreasonable; quality and ethical standards of accounting practitioners uneven, and the leaders of the unit's behest and other causes distortion of accounting information; in order to conceal the true financial condition and operating results, any alteration and falsification of false accounting documents, accounting books and accounting result the reports provide information distortion; partial accounting personnel violate accounting professional ethics, not seriously exercise accounting supervision powers involved in illegal activities and discipline, and even make plans for the irregularities and other activities.

\section{To Improve Countermeasures of Small Board Listed Company's Internal Accounting Controls}

Small plates of internal accounting controls there are all these problems, it is an indisputable fact. Deal with the problems, how to improve the internal accounting control, corporate issues at stake. With China's accession to the WTO and the deepening of enterprise reform, building internal accounting control is the small board listed company turnaround organizational needs in favor of small plates listed companies into the big environment, and actively tackle various risks and better participate in the international competition were to go.

\subsection{To Increase the Awareness for Building of the Importance of Internal Accounting Control}

Environmental factors, internal accounting controls, including social enterprises, especially employees and managers of the enterprise internal accounting control awareness and action, these environmental factors have a significant impact on the construction and implementation of internal accounting controls. Currently, many small plates listed companies enjoy leadership "only right" sense of superiority, even to manipulate the company's stock, the quality of accounting information is a serious distortion. At this point, should strengthen the oversight function of the board of directors, board of supervisors reshape the image, the quality of information disclosure norms, increase personal "Accounting Law" and "Internal Accounting Control Standards" and other propaganda laws and regulations, improve the social, business and enterprise employees, especially enterprise management and the senior management of the enterprise awareness of the importance of internal accounting controls, to really will establish and implement internal accounting controls as a long-term task, emphasizing the design and implementation of internal accounting controls, establish internal accounting controls system, clear responsibility to the agencies permission strict supervision of accounting procedures, construction and implementation of the business in line with the actual legal norms, coordination, scientific internal accounting control system.

\subsection{Attaching Great Importance to the Supervisory Role of Internal Audit}

\subsubsection{Strengthening Internal Oversight}

Under normal circumstances, the inspection and evaluation of internal accounting control is done by the internal audit, internal audit is an important part of internal control, is a special form of internal control. Small and medium-sized plate should establish internal audit departments within the enterprise, under the leadership of the company's management directly, independently to exercise the audit supervision. Internal audit should be the development of internal accounting control, management of internal accounting control system in the process of implementation, play a supervisory role in the internal accounting control system and other evaluation and 
management, designed to strengthen the internal audit system.

\subsubsection{Strengthening External Oversight}

The first is the government's supervision of internal accounting controls. Governments at all levels should supervise and guide enterprises to gradually establish an effective internal accounting controls, strengthen the implementation of internal accounting controls, internal accounting controls of the implementation of the law enforcement inspection. The implementation of internal accounting controls work better for enterprises and individuals in recognition of the poor implementation of law refused even to set up enterprises and individuals of internal accounting controls be punished in order to achieve the purpose of the law seriously. Secondly, it must play a role in taxation, auditing and other functional departments. Various functional departments within the duties and powers of initiative guide enterprises establish sound internal accounting controls, and pay attention to strengthening all aspects of communication, and actively organize the exchange of experience, regularly informed of the situation, an effective supervision.

\subsection{Improving the Personal Quality of Internal Accounting Control}

\subsubsection{Strengthening the Personal Training of Internal Accounting Control}

Implement internal accounting control depends on the quality of the staff of each one. Includes two aspects: First, you must have a good sense of responsibility, to determine their own important role and responsibility in their work, develop rigorous style of work; on the other hand, must ensure that their operational capacity with their duties fairly, in business unusual problem, it is possible to detect and take timely measures. Therefore, professionals must constantly update their knowledge, in order to timely respond to changes in objective circumstances, the practical implementation of the relevant system, the internal accounting control work of the units do a good job. In-depth study “Accounting Law” and propaganda work, the unit can be internal staff to work results every aspect of conscious comparison with the requirements of the internal accounting control system, and consciously required internal accounting control system to regulate their own behavior.

\subsubsection{Effectively Stimulating and Mobilizing Their Enthusiasm and Creativity}

Effective supervision and control of the employee behavior is an important way for enterprises to reach highefficiency goals. We can take the following measures to improve their behaviors, for example: the boss determines the bonus and motivates staff through the stock and pension scheme rewards. At the same time, the enterprise needs to timely promote and regulate the development of the talent management market, improve the management level of the modern entrepreneurs to settle the industry competitive pressures. All in all, the non-monetary incentives and constraints can play an important role in the effective supervision. In contrast, the accounting personnel that violates the internal accounting control systems and results in distortion of accounting information, in addition to other relevant provisions, the loss caused by the quality need the accounting officer to implement economic sanctions. In the theory, although various regulatory powers grow, the system of accountancy professional ethics and accounting information is still false. The actors themselves to increase financial penalties, shake its vital interests, should be a feasible solution.

This paper is on the basis of reading a lot of literature, carrying research, discussing and analyzing the internal accounting control theory. And making them as the theoretical bases of the paper, at the same time, combined with the current situation of small plates of accounting internal control, in particular, for the small and medium board listed company, its internal accounting control activities awareness is persistently weak, the internal audit is unscientific, and levels of staff and other issues are low. It can be combined with the actual characteristics of the small plate's management to make more comprehensive and effective measures to improve the internal accounting control, so that the internal accounting can play a better control and management role.

A sound internal control system is to ensure the development of small and medium enterprise board, always adhere to under the constraints of national laws, regulations and policies, strict compliance with the law, and perform their duties seriously. Internal accounting control system is the only way to give full play to its management mechanism, and it can ensure efficient operation, improve enterprise management level and ensure safe and effective operation of internal control mechanisms. It's an important guarantee for small and medium-sized enterprise board continuing to explore the development in the fierce market competition. 


\section{Funding}

This paper is supported by the Beijing Institute of Materials Research Funding (0541604904).

\section{References}

[1] An, X. (2012) Internal Accounting Controls Limitations of Analysis. The Friends of the Accounting, No. 23, 77-79.

[2] Cook (1991) An Assignments of Voluntary Disclosure in the Annual Reports of Japanese Corporations. International Journal of Accounting, 26, 174-189.

[3] Ogneva, M., Subramanyam, K.R. and Raghunandan, K. (2006) Internal Control Weakness and Cost of Equity: Evidence from SOX Section 404 Disclosure. Financial Accounting and Reporting Section (FARS) Meeting Paper, Vol. 14, 131-153.

[4] Hammersley, J.S., Myers, L.A. and Shakespeare, C. (2007) Market Reactions to the Disclosure of Internal Control Weaknesses and to the Characteristics of those Weaknesses under Section 302 of the Sarbanes Oxley Act of 2002. Working Paper Series, Vol. 16, 111-156.

[5] Chen, L.J. (2011) Analyse the Problems of Internal Accounting Control and Countermeasures. Modern Business, No. 3.

[6] Liu, N. (2011) The Theory of Enterprise Internal Accounting Control. Western Finance and Accounting, No. 5, 37-40.

[7] Zhou, X.H. (2010) The Thinking of Optimizing the Internal Accounting Control. The Finance: Academic, No. 3, 121-122.

\section{Submit or recommend next manuscript to SCIRP and we will provide best service for you:}

Accepting pre-submission inquiries through Email, Facebook, LinkedIn, Twitter, etc.

A wide selection of journals (inclusive of 9 subjects, more than 200 journals)

Providing 24-hour high-quality service

User-friendly online submission system

Fair and swift peer-review system

Efficient typesetting and proofreading procedure

Display of the result of downloads and visits, as well as the number of cited articles

Maximum dissemination of your research work

Submit your manuscript at: http://papersubmission.scirp.org/ 